\title{
Relação dos damnos causados pela invasão paragua-ya, nas igrejas da \\ comarca Ecclesiastica do Baixo Paraguay a meocargo, na Província de Mato Grosso
}

\section{Na Villa de Corumbá}

A Igreja Parochial, construída de pau a pique, foi destruída, calculando-se

o prejuízo em..... 4:000\$000

3 sinos com mais ou menos $350 \mathrm{~kg}$ de bronze a 1.200 reis $380 \$ 000$

1 jogo de armamentos novos, com os pertences ..... $400 \$ 000$

1 dito uzado, na importância de $250 \$ 000$

1 banqueta de castiçaes, cruz, etc. $100 \$ 000$

Vários objectos de alfaias pertencentes ao culto. $100 \$ 000$

\section{Miranda}

A Igreja Parochial que eu estava construindo foi destruida.

A importância de sua construcção, como constava do respectivo livro, que perdi no Paraguay, onde fui levado prisioneiro da dita Villa de Miranda, subiu de 8:000\$000

3 Imagens bronzeadas por. $420 \$ 000$

5 Sinos com $1800 \mathrm{~kg}$. de bronze a 1.200 reis $2: 260 \$ 000$

1 baqueta com cruz, na importancia de.... $108 \$ 000$

1 jogo de armamentos completos no valor de. $400 \$ 000$

Varios utensilios necessarios ao culto na importancia de $100 \$ 000$ 


\section{Nioac}

Uma igreja filial que não foi destruída, mas se achou menos arruinada

cuja construcção custou

$1: 500 \$ 000$

2 Sinos com duzentas libras de bronze.

$240 \$ 000$

1 jogo de armamentos novos na importancia de. $400 \$ 400$

2 cadeiras de braços, que juntamente as outras alfaias,

foram conduzidas commigo para o Paraguay $60 \$ 000$

\section{Albuquerque}

Uma Igreja Parochial pequena, que não foi destruída,

e se achou arruinada, cuja construcção avalio em . $4: 000 \$ 000$

2 sinos com . . . . libras de bronze. $180 \$ 000$

1 jogo de armamentos completos. $400 \$ 000$

1 turibulo de prata $90 \$ 000$

1 Imagem trocada por $100 \$ 000$

Varios utensilios para culto $100 \$ 000$

\section{Missão do Bom Conselho}

Uma igreja construida por mim, que não foi destruida, e que se achou mui Arruinada cuja construcção foi de. $6: 000 \$ 000$ 1 sino com 150 libras de bronze, e que ainda está na

Igreja de Caacupé no Paraguay na importancia de $180 \$ 000$

1 ornamento em não bom estado na importancia de $300 \$ 000$

Varias alfaias como seja commoda, cadeiras, etc $150 \$ 000$

$$
\text { S. ........Rs. }
$$

$30: 218 \$ 000$

Nota - De todos estes objectos que foram levados ao Paraguay, e muitos por mim vistos nas Igrejas da Republica, quando estive prisioneiro só dous sinos voltarão um que foi de Corumbá, e outro dos que foram de Miranda, como se pode ver actualmente, pois os collo-quei cada um em seu lugar, quando em 1870, restabeleci o culto religioso nesta comarca.

Vigararia da Vara do Baixo Paraguay, em Corumbá, 2 de janeiro de 1874. Vigário da Vara e Parocho - Frei Mariano de Bagnaia

Objectos que forão mandados por S. A. o Conde d'Eu, por intermédio do Senr. Bispo Dio-cesano, e que se achão já distribuidos em 1870. 


\title{
Para a igreja de Corumbá:
}

1 turibulo de prata -3 casulas em mão estado -1 custodia de prata -1 cruz de prata -1 ambula de prata -1 jarro de prata -1 calix de dita.

\section{Para a Igreja de Miranda:}

1 custodia de prata - um turíbulo de prata.

Corumbá, 4 de fevereiro de 1874

\section{O Vigario e Parocho}

\author{
Fr. Mariano de Bagnaia \\ José Antonio dos Reis
}

